\title{
Training Subjects On Key Concepts From Patient-Reported Outcomes (PROs) Improves Understanding And Data Accuracy [Corrigendum]
}

Dias NR, Howley AR, Yamamoto R, et al. Patient Relat Outcome Meas. 2019;10:315-319.

Upon reviewing the article, the authors noticed an error in Figure 1 on page 318 , it should be presented as follows:

Mean Accuracy Response (5 PROs)

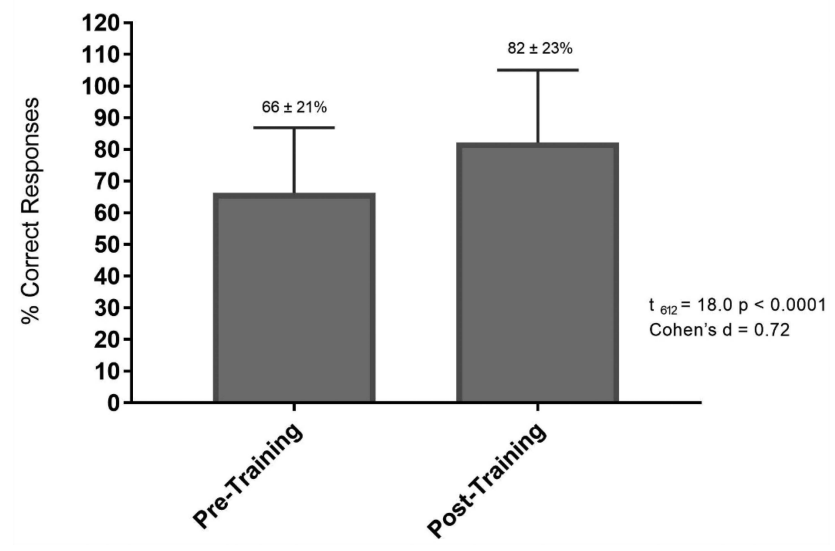

Figure I Mean accuracy response (5 PROs).
The y-axis on the figure previously provided did not accurately reflect the values written within the text of the paper as well as the values written above the error bars on the figure itself. Therefore, the authors have made the corrections to the $y$-axis. This change does not alter the findings reported in the results. The authors apologize for this error.

\section{Publish your work in this journal}

Patient Related Outcome Measures is an international, peer-reviewed, open access journal focusing on treatment outcomes specifically relevant to patients. All aspects of patient care are addressed within the journal and practitioners from all disciplines are invited to submi their work as well as healthcare researchers and patient support groups.

The manuscript management system is completely online and includes a very quick and fair peer-review system. Visit http://www. dovepress.com/testimonials.php to read real quotes from published authors. 